\title{
College English Teaching Reform on the Background of College Entrance Examination English Course Reform
}

\author{
$\mathrm{Li} \mathrm{Bi}$ \\ Teaching and Research Institute of Foreign Languages, Bohai University, Jinzhou, 121013, China \\ 36143096@qq.com
}

Keywords: national college entrance examination reform; English course; college English; teaching reform; reform content

\begin{abstract}
College entrance examination reform program has aroused widespread concern in the community, and change of the way of English exam presents new challenges for college English teaching. This paper studies for realizing the seamless connection between the basic English teaching and college English teaching, which solves the problem of college English teaching after college entrance examination English courses reform and has important significance in improving college English teaching quality. Based on college entrance examination English reform measures, in-depth analyzing the impact of college entrance examination English reform for college English teaching, pointing out the reform content of college English teaching. Major reform content include: add rich and practical English courses for specific purpose, adjust college English courses and requirements, highlight professional characteristics of student-centered and comprehensively improve the comprehensive ability of English employability.
\end{abstract}

\section{Introduction}

"Opinions of the State Council on deepening the reform of examination enrollment system" points out, with over 30 years of reform and opening up, China's examination enrollment system is constantly improved, initially forms a relatively complete examination enrollment system and makes a historic contribution for students' growing, the state election and social justice, which has played an irreplaceable role in improving the quality of education, enhance national quality, promote social longitudinal flow and serve the country's modernization. This system generally consistent with national conditions, authority and fairness are recognized by society, but there are some problems strong reflected from social, the main is that only score theory can affect the overall development of students, a test for life makes students overburdened, regional, admission opportunity for urban and rural has gap, primary and secondary school choice phenomenon is more prominent, plus fraud, illegal recruitment phenomenon have occurred. To implement the decision and deploy of Party Central Committee and State Council, deepen the reform of examination enrollment system [1].

English has the most important component and the highest social cognition in the China's national education career. After the college entrance examination reform, English implement social exams, twice a year, and six times in three years. College entrance examination did not diminish the importance of English, but consolidate the absolute position of Chinese, mathematics, foreign language as the main subjects. Candidates have many opportunities to participate exams to achieve the highest score. This means that if a candidate can seize the opportunity in their English with best level and to test out the best results as soon as possible in senior one, then you can take more time to study other subjects [2]. College entrance examination English reform has original meaning to return to foreign language education, English society examination will bring major changes for school's teaching. College entrance examination English reform will cool English fever to make that English learning is no longer a universal engineering, and it will return to a normal state. This directly affects the college English teaching philosophy. After the reform of college entrance examination in English, English teaching will face adjustment in class schedule, course content, syllabus, etc., college English teaching need to re-adapt the changes, curriculum system, curriculum 
standards, class number, teaching content, teaching mode, teaching outline and other aspects will be faced with new challenges, we must make the appropriate adjustments and changes, so that the basic English teaching and college English teaching can achieve seamless connection [3].

\section{The College Entrance Examination English Reform Measures}

College entrance examination English reform program can be seen that in guidelines and requirements, test content and test methods and so on, specific reform measures are as follows:

(1) Emphasize the language communication. The general idea of the college entrance examination reform includes reducing the burden, balance and fair. English proposition also will be conformed to new curriculum requirements, fully embodies the guiding ideology of "development in the stability" and the proposition principle of "highlight discourse, emphasize the language communication, focus on actual language environment of English use and practical application of English", to further reflect humanities, highlight context, discourse test to cultivate students' abilities of using English comprehensively.

(2) Reduce the burden on students. College entrance examination English reform, through restructuring in the papers, the change of papers scores and rational enrollment pattern, releases a clear signal to the whole society to let them to see the resolution and target of this reform from critical examination change, thereby establishing confidence for parents, students and teachers to untie students in all aspects, reduce the burden on students, let them to learn the content of interest, parents can reduce stress and economic burden at the same time.

(3) Examination socialization, more than one exams test in a year. Foreign language is no longer involved in college entrance examination, students can choose examination time and frequency by themselves, and enhance the option, and make the expression and use of foreign language scores tend to be more scientific and reasonable. From the situation in many countries, the Government exit exam industries, agency stars run, it has become a major trend. Examinations are entering the market, industry, folk and pluralism stages. At the same time, the examination socialization also can create a barrier between college entrance examination and high school education, so that high school education do not get too much interference from the college entrance examination, eliminate poor wind of school choice and the existence soil of examination-oriented education, so that quality education is truly implemented.

(4) Emphasis on practical skills. For a long time, college entrance examination English focuses on vocabulary, grammar and sentence, emphasis on writing and "reading." College entrance examination English reform more emphasizes on English practicality. On the one hand, emphasizing speaking, reading and writing skills, on the other hand, English learning content tend to be more professional and practical. Teachers focus on grammar teaching, and then instill grammar knowledge to students according to textbooks, which can bring an illusion to students that if they master the grammar and recite a lot of grammatical rules, they will master the English, in fact, this is just one of the teaching task. English teaching is not explaining grammatical theory, rather than the practical ability.

\section{College Entrance Examination English Reform's Influence on College English Teaching}

College entrance examination English reform had a significant impact on college English teaching, mainly in the following aspects:

(1) Teaching positioning of college English. Positioning is the focus of college English education reform in recent years. Related survey of college English learning for this problem shows that: 66\% of surveyed students think that college should adopt EGP model, $27 \%$ of the students think should use ESP model, 7\% of the students think should strengthen EAP teaching. Seen in this light, in the case of the college entrance examination reform has not fully appeared, ESP model is not most students' needs. So after the college entrance examination reform, even enthusiasm of students learning English will not have any change, we can not guarantee the students' English ability has improved significantly. 
(2) Connection between basis English education and college English education. English learning ability of students training in basic education determines the direction of the college English curriculum, but also determines the teaching effects. This stage, the difficulty of college entrance examination in different provinces is different. After English reform, the level of English will be greater differences in the provinces. Meanwhile, the policy of twice a year will make some students give up learning English periodically when they get the ideal result at the first test, which will affect students' English learning after entering the college. At the same time, it will present challenge for college English curriculum design. Therefore, explore curriculum system to interface the basis English and college English, is the key issue of the future English education.

(3) Develop diversified English curriculum objective [4]. College entrance examination English reform led the educational values in the new period, in accordance with the national education policy, the objective of college English new curriculum should be based on the needs of society and students' knowledge level conditions, in the process of learning English in college for two years, students can achieve the desired objective by completing specified education tasks. Course objective seeks to diversify by implementing uniform requirements into developing diversity. In the cognitive aspect, students through their knowledge understand the internal structure and link of English, and building thinking to learn English and skills to perceive language based on language knowledge; in skill aspect, grasp the logic of English thinking, unify the external verbal expression with internal speech ponder, master English practical habits and rules, communicate properly in English; in emotion aspect, learning Western values, integrate cultures, thoughts, ideas and beliefs of the Chinese and Western, seek common points while reserving difference; in the application aspect, improve students' ability to use English, using the above three aspects to solve practical problems encountered in work and life.

(4) Comprehensive language application ability training becomes focus. For language learners, "listen and speak" is the foundation, and "read and write" is higher stage learning. "Listening and reading" is the input process of language learning, "speaking and writing" is the output process of language learning. "Listening, speaking, reading and writing", they promote and upgrade. Ability to communicate is the most important language skill, college English teaching should target to communicate, English language communication of everyday life is a basic requirement, the ultimate goal of college English teaching is to exchange expertise using English; English reading ability is an important ability to acquire knowledge, and this ability determines later learn and work ability to a large extent, on the one hand consolidate basic and application of English language learning, on the other hand lay a good foundation for exploring and studying their expertise; English appreciation is a prerequisite for art and cultural exchanges, the main purpose of English teaching is not only practical application of language, it should become the way to spread world's culture and art. By learning the language, students can learn more about and enjoy the culture and art of English-speaking countries.

\section{College English Teaching Reform Content}

College English teaching reform had a major impact on college English teaching, so college English teaching reform must be carried out in order to eliminate the effects, improve students' English application ability, return to the essence of English education. College English teaching reform content mainly from the following aspects [5-8]:

(1) Add rich and practical English courses for specific purpose for different professions and different needs students to choose. ESP, it refers to English related to a specific profession, discipline or purpose. ESP has three absolute characteristics, namely: meet the specific needs of language learners; use methods and activities related with service disciplines; grammar, vocabulary, context, study skills, discourse and genre as center. ESP has five variable characteristics: it may be associated with a particular subject; in particular teaching situation, it may use a different method with general English; most service for higher education or career working of adult learners; usually design for secondary students or honors; require basic knowledge of language system in the learning process. The main branches of ESP have scientific English, business English and social 
science English, each area is divided into academic English and vocational English two branches, which is shown in Fig.1. Jordan takes the ultimate goal of language learners and language environment as the main line, the ESP can be divided into vocational English and academic English, and academic English is divided into specialized academic English and general academic English, as shown in Fig.2. ESP has a unique vocabulary, syntax and structure, teaching not only includes the training of English language skills, but also have significant professional connotation, it is a combination of language skills and professional knowledge, and the main purpose of opening ESP course is to "strengthen foundation, broaden profession, improve ability and apply their knowledge". ESP belongs to improvement stage of EGP, and it is an extension of EGP, but ESP has clearer teaching purposes that cultivate students' practical ability in the target context, which has more pertinence, practicability and profession.

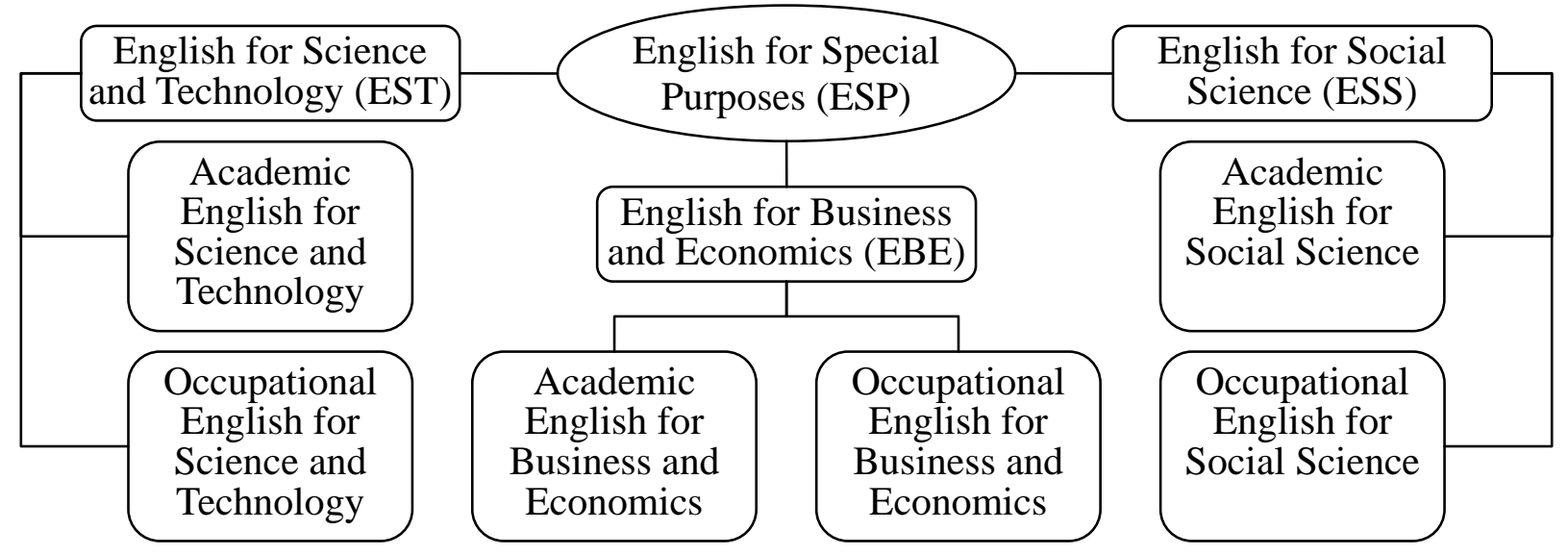

Fig. 1. Three classification on English for special purposes

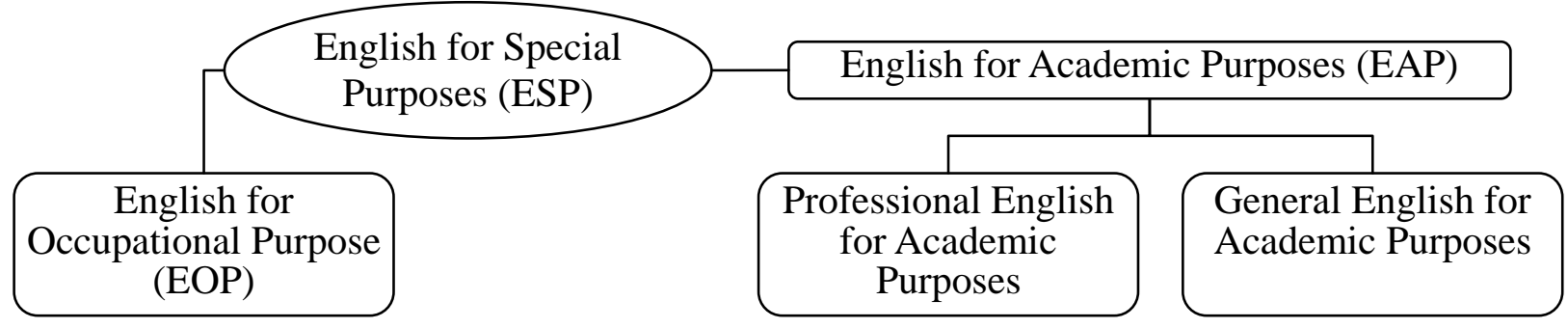

Fig. 2. Two classification on English for special purposes

(2) Adjust college English courses and requirements to improve teaching effectiveness. China is a vast, so education level is uneven, there is a large gap between freshmen, the universities shall determine college English class and credits based on training objectives and school characteristics, rather than the majority of colleges and universities now, arrange them to one class, no matter they come from different provinces or regions, develop a unified class, credits and evaluation criteria. Such setting may bring erroneous perception about college English to outstanding students, and they will think that the college English is the repetition of high school English, lack of challenge. The relatively low level of students in order to catch up with the overall progress of English learning, they have to pay a lot of time. In order to improve students' English proficiency, the first is to break the "one size fits all" situation of current college English teaching, and ensure the efficiency of learning. Learning English has a variety of combinations: planning an individual English learning program in elementary stage based on their level of English and demands, you can take a year of college English learning, and a year of language application skills learning; designing speaking, vocabulary, reading and writing and other special college English skills courses.

(3) Highlight professional characteristics of student-centered. Each profession determines training objectives according to positioning analysis, and college English curriculum should keep up with professional characteristics to refine course objectives and course content. It is mainly reflected in three aspects: first, course credits. Although the college entrance examination scores 
lower in English, English has always been popular in the world, representing the advanced science and technology, culture and fashion, stronger ease of use language. Different professions have different requirements for English level, and professional development and employment tendency determine their importance and need for English. Reasonably allocate class and credits according to individual needs of each professional, different with the previous unified model to meet students' personality development; the second is the course structure. Scope and sequence are elements for course structure, and arrange curriculum respectively from longitudinal and lateral. Strive to find meeting point of professions training objectives and college English courses to achieve the perfect combination. Taking into account the coverage of the course, according to the different needs of the different professional for various English skills, conducting targeted setting for comprehensive English class, language skills class, language application class, language culture class and specialized English class; third is the course content. Choice of college English curriculum content measure in the future more likely meets the target of various professional training. Compared to basis English, various professional emphasizes on language application skills. College English curriculum content has an auxiliary for mastering the building of professional knowledge structure, which is the expansion and extension of expertise, thereby contributing to internalize and absorb expertise.

(4) Comprehensively improve the comprehensive ability of English employability. Tamp foreign language foundation, strengthen employment orientation, reform in terms of teaching content, teaching methods and teaching means. Teaching content aspect, achieve the combination of professional and English to overcome break-off phenomenon between them. The combination of professional and English can increase purpose of l English earning, stimulate the enthusiasm and initiative to learn English. At the same time, increasing professional content to avoid boring when learn abstract learning language; teaching methods aspect, achieve the combination of traditional teaching model and task-based teaching model. Traditional English teaching model focuses on systematic of imparting knowledge, training the basic theory and basic knowledge of English, but teaching is too rigid, students are not interested. Task-based teaching model focuses on the purposive communication and language expression, and emphasizes the learning process, the language can be applied to life or work to develop students' creative thinking to solve practical problems, teaching process is lively, and it more likely to cause interest in learning English, but easy to overlook the learn and culture of basic knowledge. The combination of them can achieve more with less; teaching means aspect, realize the combination of traditional means and modern means. Traditional teaching means is that teachers speak, students listen, teachers write and student look, the form is single and boring. Modern teaching means can not only use vivid courseware, you can also take advantage of modern sound and light technology and film technology to stimulate students' curiosity and interest in learning. Organic combination of the two, both to ensure that master the English basic knowledge, but also can active in the classroom atmosphere.

\section{Conclusion}

College entrance examination English reform although can not shake the important position of college English teaching, but bring an impact and challenges to college English teaching. Whether English quit college entrance examination, cancel listening test or reduce the weight of the English score, College entrance examination English reform will bring great impact on college English teaching. College English teaching follows the principle of individualized, the reform will determine the level of English and the ability change of students, so we need to adapt basis English teaching after reformed. After the reform, English teaching will face adjustment in class schedule, course content, and syllabus and so on, and English socialization exam will affect students' English proficiency and application ability. College English teaching need to re-adapt the changes, curriculum system, curriculum standards, class number, teaching content, teaching mode, teaching outline and other aspects will be faced with new challenges, we must make the appropriate adjustments and changes, so that the basic English teaching and college English teaching can achieve seamless connection. Future college English teaching more emphasis on applications of 
language, logical thought and expression, good language organizational skills, good cultural background knowledge about English countries, these have become an important part and basic concerns of college English teaching [9-11]. Results of this study solved the problem of college English teaching after the reform of college entrance examination English, which have great significance in adapting to the college entrance examination English reform and improving college English teaching quality.

\section{Acknowledgement}

This work is supported by Education science planning project in Liaoning province (JG14DB007): College English Teaching Reform on the Background of College Entrance Examination English Course Reform.

\section{References}

[1] The Central People's Government of the People's Republic of China, "Opinions of the State Council on deepening the reform of examination and enrollment system," http://www.gov.cn/zhengce/content/2014-09/04/content_9065.htm, 2015-11-13.

[2] College entrance examination network, "Interpretation of the new program in 2017 college entrance examination reform," http://www.gaokao.com/e/20150814/55cd8b270b4bf.shtml, 2015-11-13.

[3] Y. D. Zhao, "The importance of College English teaching from the perspective of the reform of college entrance examination," Intelligence, vol. 14, no. 21, pp. 22-23, 2014.

[4] X. Wang, "On the development trend of College English curriculum reform from the perspective of college entrance examination reform," Heilongjiang Researches on Higher Education, vol. 33, no. 7, pp. 149-151, 2014.

[5] Y. Song, Y. B. Wang, "ESP: Characteristics, Taxonomy and Current Research in China," Journal of Shenyang University (Social Science), vol. 16, no. 4, pp. 554-557, 2014.

[6] J. Zhao, "A study of College English Teaching Reform under the background of planning of college entrance examination in English," Journal of Agricultural University of Hebei (Agriculture and Forestry Education Edition), vol. 17, no. 1, pp. 62-65, 2015.

[7] Y. L. Wang, "A Summary of English for Specific Purposes," Journal of Central South University of Forestry \& Technology (Social Sciences), vol. 2, no. 6, pp. 108-110, 2008.

[8] L. H. Huang, "Countermeasures of College English Teaching in the reform of college entrance examination," Chinese off campus education, vol. 8, no. 30, pp. 96, 2014.

[9] L. Bi, "Research on College English Teaching Reform under the new situation of college entrance examination," Journal of Liaoning Educational Administration Institute, vol. 32, no. 4, pp. 65-67, 2014.

[10] Y. Q. Zhang, "The importance of College English teaching from the perspective of the reform of college entrance examination," Outstanding Figures, vol. 13, no. 10, pp. 145, 2013.

[11] L. L. Song, "On the reform of College English teaching mode under the background of college entrance examination," Journal of Heilongjiang College of Education, vol. 33, no. 3, pp. 157-158, 2014. 